\title{
МИКРОВОЛНОВОЙ СИНТЕЗ МЕТАЛЛООРГАНИЧЕСКИХ КООРДИНАЦИОННЫХ ПОЛИМЕРОВ НА ОСНОВЕ МЕТАЛЛОКОМПЛЕКСОВ ФТАЛОЦИАНИНОВ
}

\author{
К.Е. Моисеева, Е. С. Головашова, Т. А. Агеева, О. И. Койфман \\ КСЕНИЯ ЕВГЕНЬЕВНА МОИСЕЕВА - аспирант кафедры Химии и технологии высокомолекулярных \\ соединений ФГБОУ ВО «Ивановский государственный химико-технологический университет». Область \\ научных интересов: синтез порфиринсодержащих полимеров и новых функциональных материалов на их \\ основе.E-mail: 13.06.mois.ksen@bk.ru.
}

ЕЛЕНА СЕРГЕЕВНА ГОЛОВАШОВА - кандидат химических наук, научный сотрудник кафедры Химии и технологии высокомолекулярных соединений ФГБОУ ВО «Ивановский государственный химикотехнологический университет». Область научных интересов: синтез, строение и свойства природных и физиологически активных веществ; медицинская химия и прогнозирование различных видов биоактивности.E-mail: alen6283@mail.ru.

ТАТЬЯНА АРСЕНЬЕВНА АГЕЕВА - кандидат химических наук, дочент кафедры Химии и технологии высокомолекулярных соединений» ФГБОУ ВО «Ивановский государственный химико-технологический университет». Область научных интересов: синтез и исследование порфиринсодержащих полимеров и новых функииональных материалов на их основе. E-mail: tageeva@isuct.ru.

ОСКАР ИОСИФОВИЧ КОЙФМАН - президент Ивановского государственного химико-технологического университета, член-корреспондент РАН, доктор химических наук, профессор, заведующий кафедрой Химии и технологии высокомолекулярных соединений ИГХТУ, научный руководитель института макрогетероииклических соединений ИГХТУ, заслуженный деятель науки, лауреат премий Правительства РФ в области науки и президента РФ вобласти образования. Известный специалист в области физической, координационной и синтетической химии тетрапиррольных макрогетероциклов и порфиринполимеров.

153000, Россия, Иваново, пр. Шереметевский, д. 7, Институт макрогетероциклических соединений Ивановского государственного химико-технологического университета.

В условиях микроволнового излучения и термического нагрева получены металлоорганические каркасные структуры (МОКС), методом конденсации и терефталевой кислоты с металлокомплексами октакарбоксифталочианина или тетракарбоксифталочианина в диметилформамиде. Исследованы физико-химические свойства МОКС методами ИК-спектроскопии, электронной проникающей микроскопии и термогравиметрического анализа ДСК. В ИК спектре синтезированного материала наблюдается ряд характеристичных полос, отвечающих за валентные колебания связей $C=O$ в карбоксильных группах, и полосы, характерные для фталоцианинового макрочикла. Согласно данным термического анализа установлено, что МОКС, полученные на основе фталоцианинатов металлов в интервале температур от $18{ }^{\circ} \mathrm{C}$ до $300{ }^{\circ}$ С в инертных и окислительных условиях теряет менее $35 \%$ от своей массы.

Ключевые слова: микроволновой синтез, фиалоцианинаты металлов, металлоорганические каркасные структуры, координационные полимеры. 


\title{
MICROWAVE SYNTHESIS OF ORGANOMETALLIC COORDINATION POLYMERS BASED ON CARBOXYPHENYLPORPHYRINATES OF METALS
}

\author{
K. E. Moiseeva, E. S. Golovashova, T. A. Ageeva, O. I. Kojfman \\ 153000, Russia, Ivanovo, Sheremetevskii av., 7 Research Institute of Macroheterocyclic Compounds, Ivanovo State \\ University of Chemistry and Technology.
}

Under the conditions of microwave radiation and thermal heating, organometallic framework structures (MOF) were obtained by condensation of terephthalic acid with metal complexes of octacarboxyphthalocyanine or tetracarboxyphthalocyanine in dimethylformamide. The physicochemical properties of MOF were investigated by IR spectroscopy, electron penetration microscopy, and thermogravimetric DSC analysis. In the IR spectrum of the synthesized material, a number of characteristic bands are observed, which are responsible for the stretching vibrations of $C=O$ bonds in carboxyl groups, and bands characteristic of the phthalocyanine macrocycle. According to the thermal analysis data, it was found that MOF obtained on the basis of metal phthalocyaninates in the temperature range from $18^{\circ} \mathrm{C}$ to $300^{\circ} \mathrm{C}$ under inert and oxidizing conditions loses less than $35 \%$ of its mass.

Keywords: microwave synthesis, metal phialocyanines, organometallic framework structures, coordination polymers.

Металлокомплексы тетрапиррольных макрогетероциклических соединений (ТПМГЦ) являются исходными мономерами для различных типов координационных полимеров, представляющих собой особую группу структурно-организованных систем $[1,2]$. Они образуются благодаря способности металлопорфиринов и их аналогов к экстракоодинации (аксиальной координации) центральным атомом металла различных органических молекул [3-5]. Большинство ТПМГЦ, имеющих активные функциональные группы на периферии молекулы, неизбежно вовлекаются в этот процесс как полифункциональные мономеры, обеспечивающие формирование различных по структуре полимеров. Образование сложных пространственно организованных систем лежит в основе особой группы координационных полимеров, которые принято называть металлоорганическими каркасными coeдинениями (МОКС) или Metal-Organic Frameworks (MOF, MOFs). Металлоорганические каркасные соединения представляют собой гибридные нанопористые материалы, образованные ионами металлов или металлсодержащими кластерами соединенных полидентатными органическими мостиковыми лигандами (линкерами) в трехмерный каркас.

Процессы самосборки и самоорганизации металлопорфиринов и их аналогов с включением в макромолекулы органических соединений непорфириновой природы являются основной движущей силой образования координационных полимеров [6]. Условия их образования и стабиль- ность зависят от природы металла и свойств исходного синтона, лежащего в основе супрамолекулы. Для обеспечения высокого уровня структурной организации макрогетероциклических соединений в координационных полимерах необходимо наличие у исходных мономеров нескольких связывающих центров, что легко достигается во всех тетрапиррольных макрогетероциклах путем введения на их периферии активных функциональных групп. Поэтому металлокомплексы фталоцианинов, имеющие жесткий остов, являются идеальными структурными блоками для построения металлоорганических каркасных соединений.

МОКС обладают широким спектром полезных свойств, что позволяет использовать их в различных областях науки, таких как катализ, люминесценция, магнетизм, транспортировка и разделение газов, нелинейная оптика, хранение газов и энергии [7-13].

В большей части исследований в качестве синтонов МОКС использовались металлопорфирины, а металлокомплексы фталоцианинов были использованы для получения пористых материалов лишь в единичных случаях [14-17]. Этот факт, очевидно, связан с тем, что металлофталоцианины, как правило, образуют плотно упакованные агрегаты и получение пористых материалов на их основе с использованием стратегии синтеза порфиринсодержащих МОКС затруднено [18].

На примере октакарбоксифталоцианината меди (1a) ранее нами было показано, что метал- 


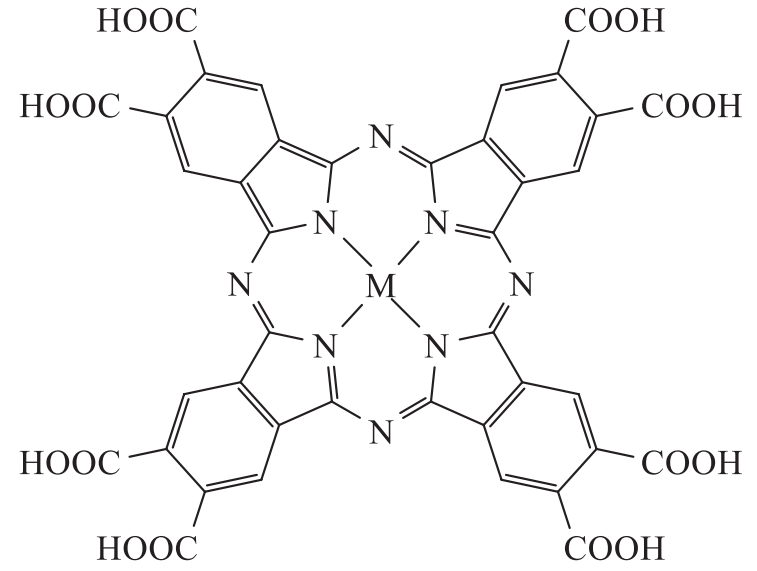

(1)

(1a) $\mathrm{M}=\mathrm{Cu}(\mathrm{II})$ - Октакарбоксифталоцианинат меди

(1b) $\mathrm{M}=\mathrm{Co}(\mathrm{II})$ - Октакарбоксифталоцианинат кобальта

(1c) $\mathrm{M}=\mathrm{Al}(\mathrm{III}) \mathrm{OH}-$ Октакарбоксифталоцианинат алюминия

(1d) $\mathrm{M}=\mathrm{Zn}(\mathrm{II})$ - Октакарбоксифталоцианинат цинка

локомплексы с фталоцианиновым лигандом могут быть использованы в качестве «строительных» блоков для получения новых высокопористых наноматериалов. При взаимодействии 4,5-октакарбоксифталоцианината меди (CuOCPc) с нонагидратом нитрата алюминия в среде ДМФА впервые был получен новый высокоупорядоченный наноматериал, сине-зеленого цвета, нерастворимый ни в водных, ни в органических растворителях [19, 20].

С целью усовершенствования предложенных методов и разработки новых подходов синтеза МОКС на базе фталоцианинатов металлов нами были разработаны методы получения высокопористых материалов с использованием в качестве исходных синтонов металлокомплексы октакарбоксифталоцианина (1) и тетракарбоксифталоцианина (2) в условиях микроволнового нагрева. Синтез МОКС осуществлялся методом конденсации фталоцианинатов металлов и терефталевой кислоты в среде органического растворителя аналогично методу, описанному в работе [20]. Исследованы физико-химические свойства МОКС с помощью ИК-спектроскопии, электронной проникающей микроскопии и термогравиметрического анализа ДСК. В ИК спектре синтезированного материала наблюдается ряд характеристичных полос, отвечающие за валентные колебания связей $\mathrm{C}=\mathrm{O}$ в карбоксильных группах, и полосы, характерные для фталоцианинового макроцикла. Согласно данным термического анализа установлено, что МОКС в интервале температур от $18^{\circ} \mathrm{C}$ до $300^{\circ} \mathrm{C}$ в инертных и окислительных условиях теряет менее $37 \%$ от своей массы, что согласуется с литературными данными [20-23].

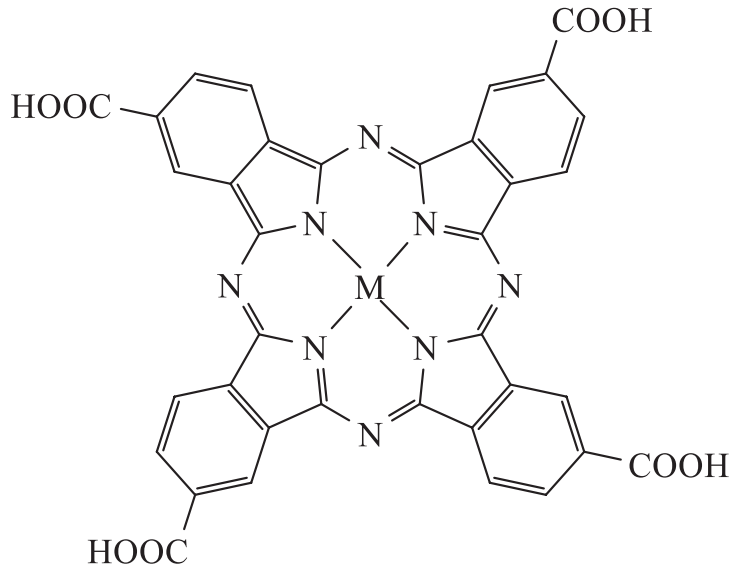

(2)

(2a) $\mathrm{M}=\mathrm{Cu}(\mathrm{II})$ - Тетракарбоксифталоцианинат меди

(2b) $\mathrm{M}=\mathrm{Co}(\mathrm{II})$ - Тетракарбоксифталоцианинат кобальта

(2c) $\mathrm{M}=\mathrm{Zn}(\mathrm{II})$ - Тетракарбоксифталоцианинат цинка

Перспективой дальнейшего исследования является изучение полученного МОКС в качестве катализатора гетерогенного окисления органических субстратов, таких как аскорбиновая кислота, морин и $\beta$-каротин кислородом воздуха, так как известно, что представители данного класса металлорганических координационных полимеров обладают подходящими для данных целей физико-химическими свойствами: высокой пористостью, разнообразием металлов и функциональных групп, высокой каталитической активностью, а также большой удельной поверхностью [9, 10].

Синтез МОКС на основе октакарбоксифталоцианината кобальта (II). В реакционный сосуд, снабженный магнитной мешалкой, загружали октакарбоксифталоцианинат кобальта (II) (1b) 40 мг (0,04 ммоль), терефталевую кислоту 20 мг (0,12 ммоль) и 3 мл ДМФА. Пробирку, закрытую заглушкой, помещали в микроволновой реактор «CEM Discover labmate microwave reactor» и peакционную смесь выдерживали в течение 40 минут при давлении 70 Па, при температуре $150{ }^{\circ} \mathrm{C}$ и мощности 100 Вт. Охлажденный продукт реакции промывали дистиллированной водой, этанолом до исчезновения окраски промывной жидкости. Полученный плав представляет собой кристаллический порошок изумрудного цвета. Выход продукта составил $82 \%$.

Полученное соединение было охарактеризовано ИК-спектрами, зарегистрированными на спектрофотометре Avatar 360 FT-IR ESP. ИК-спектры полученного продукта свидетельствует о наличии октакарбоксифталоцианината кобальта (II) в синтезированном соединении (Рис. 1). 


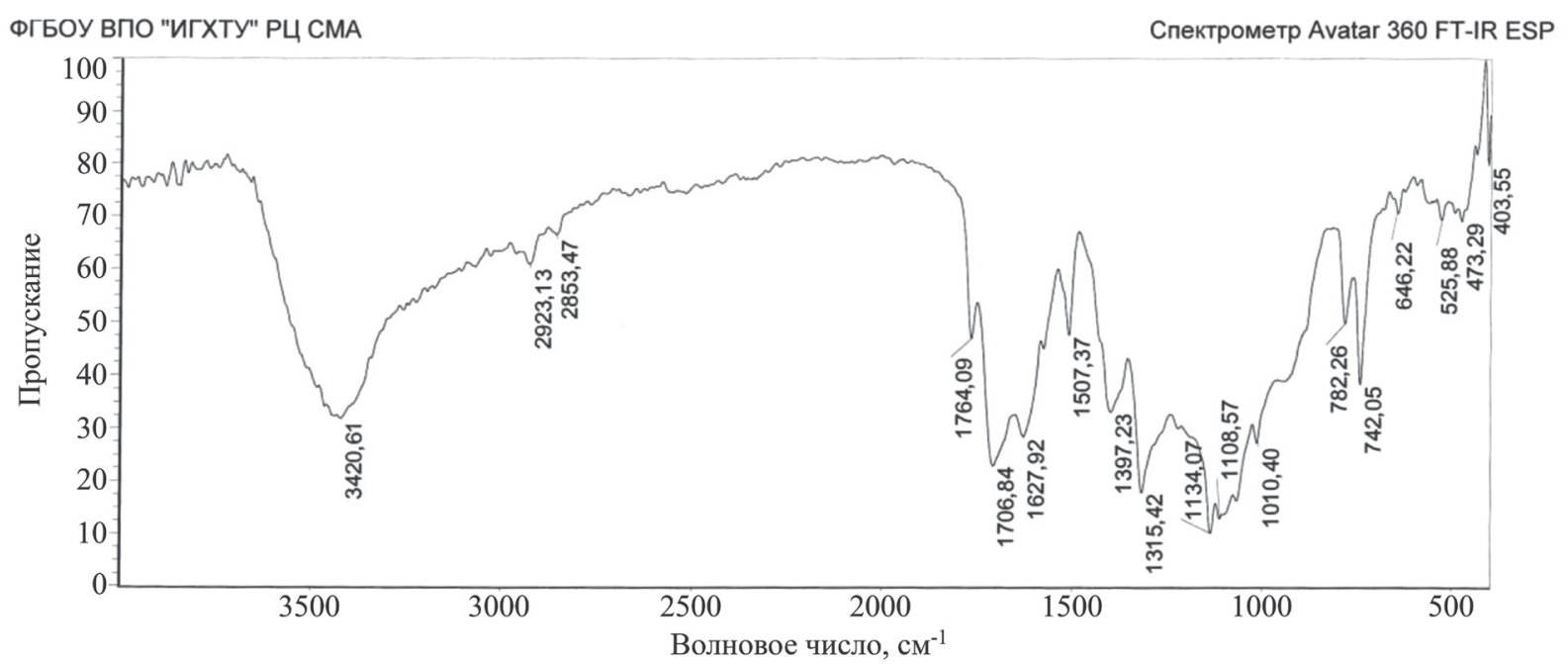

Рис. 1. ИК- спектр МОКС на основе $\mathrm{CoPc}(\mathrm{COOH})_{8}$ IR (KBr): v, cm $2923\left(-\mathrm{CH}_{3} v_{a s}\right), 2853\left(-\mathrm{CH}_{2}-v_{a s}\right), 1627(-\mathrm{C}=\mathrm{O} s t), 1507\left(-\mathrm{CH}_{2}-\delta\right), 1397(-\mathrm{C}-\mathrm{N} \mathrm{st})$

Термическая устойчивость синтезированного МОКС на основе октакарбоксифталоцианината кобальта (II) была исследована методом ДСК на приборе NETZSCH STA 449F3. Согласно данным термического анализа установлено, что полученное соединение в интервале температур от $30{ }^{\circ} \mathrm{C}$ до $400{ }^{\circ} \mathrm{C}$ в инертных условиях теряет менее $28 \%$ от своей массы (Рис. 2).

Была исследована морфология поверхности полученных МОКС с помощью сканирующего электронного микроскопа (СЭМ) Tescan Vega 3. Микрофотография поверхности МОКС на основе октакарбоксифталоцианинат кобальта (II) и его элементный анализ, полученный с помощью СЭМ, представлены на рис. 3.
Синтез МОКС на основе октакарбоксифталоцианината меди (II). В реакционный сосуд, снабженный магнитной мешалкой, загружали октакарбоксифталоцианинат меди (II) (1a) 40 мг (0,04 ммоль), терефталевую кислоту 20 мг $(0,12$ ммоль) и 3 мл ДМФА. Пробирку, закрытую заглушкой, помещали в микроволновой реактор «CEM Discover labmate microwave reactor» и реакционную смесь выдерживали в течение 50 минут при давлении 70 Па, при температуре $150{ }^{\circ} \mathrm{C}$ и мощности 100 Вт. Охлажденный продукт реакции промывали дистиллированной водой, этанолом до исчезновения окраски промывной жидкости. Полученный плав представляет собой кристаллический порошок зеленоватофиолетового цвета. Выход продукта составил 86 \%.

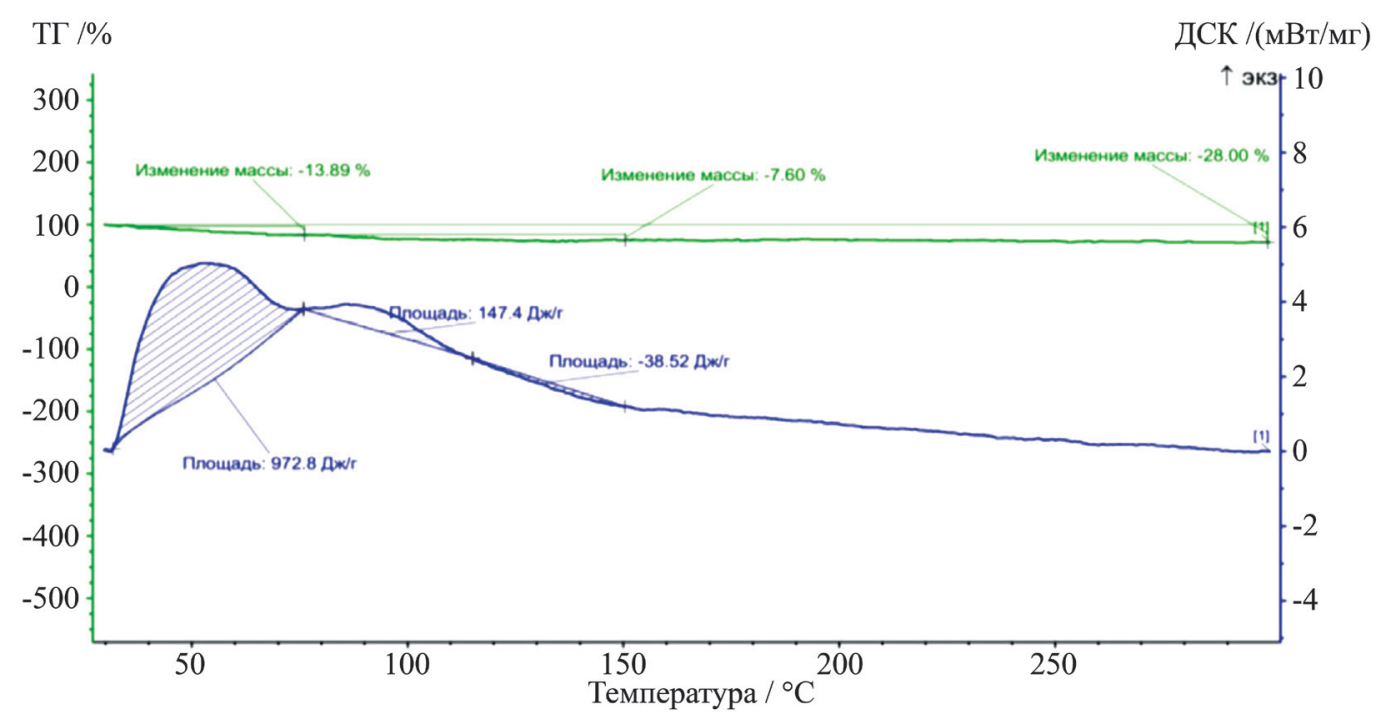

Рис. 2. Кривая ДСК и ТГ для МОКС на основе СоРс(COOH), при инертных условиях (пропускание материала в атмосфере Ar/-/Ar при температуре от 30 до $300{ }^{\circ} \mathrm{C}$ ) 

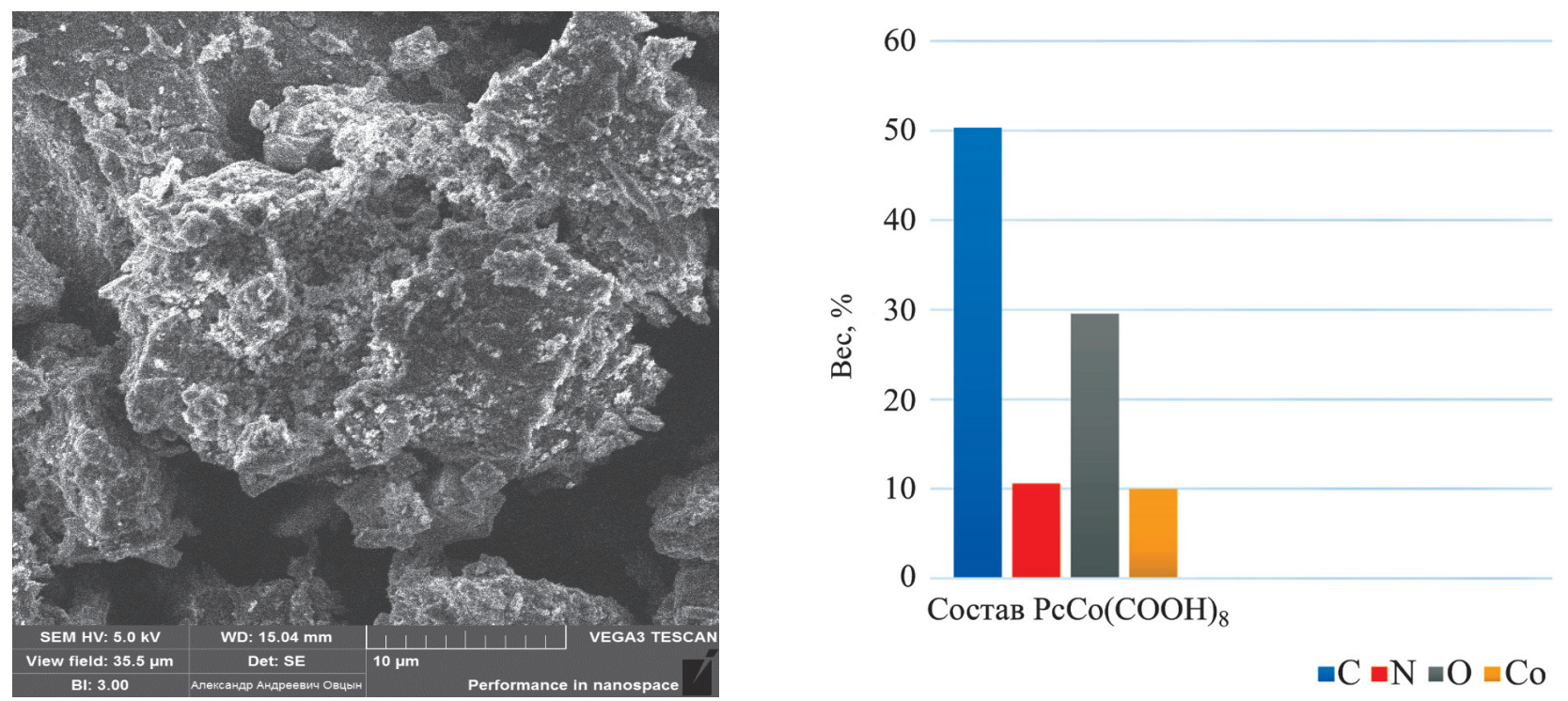

Рис. 3. Микрофотография образца МОКС на основе СоРс(СООН $)_{8}(10$ мкм) и его элементный состав, полученный методом СЭМ

ИК-спектры полученного продукта свидетельствуют о наличии октакарбоксифталоцианината меди (II) в синтезированном соединении (Рис. 4).

Согласно данным термического анализа (Рис.5) установлено, что полученное соединение в интервале температур от $30^{\circ} \mathrm{C}$ до $400{ }^{\circ} \mathrm{C}$ в инертных условиях теряет менее $32 \%$ от своей массы.

Микрофотография поверхности МОКС на основе октакарбоксифталоцианината меди (II) и его элементный анализ, полученный с помощью СЭМ, приведены на рис. 6.

Синтез МОКС на основе октакарбоксифталоцианината алюминия (III). В реакционный сосуд, снабженный магнитной мешалкой, загружали октакарбоксифталоцианинат алюминия (III) (1c) 40 мг (0,04 ммоль), терефталевую кислоту 20 мг $(0,12$ ммоль) и 3 мл ДМФА. Пробирку, закрытую заглушкой, помещали в микроволновой реактор «CEM Discover labmate microwave reactor» и peакционную смесь выдерживали в течение 50 минут при давлении 70 Па, при температуре $150{ }^{\circ} \mathrm{C}$ и мощности 100 Вт. Охлажденный продукт реакции промывали дистиллированной водой, этанолом до исчезновения окраски промывной жидкости. Полученный плав представляет собой кристаллический порошок желтовато-коричневого цвета. Выход продукта составил $51 \%$.

ИК-спектры полученного продукта свидетельствуют о наличии октакарбоксифталоцианината алюминия в синтезированном соединении (Рис. 7).

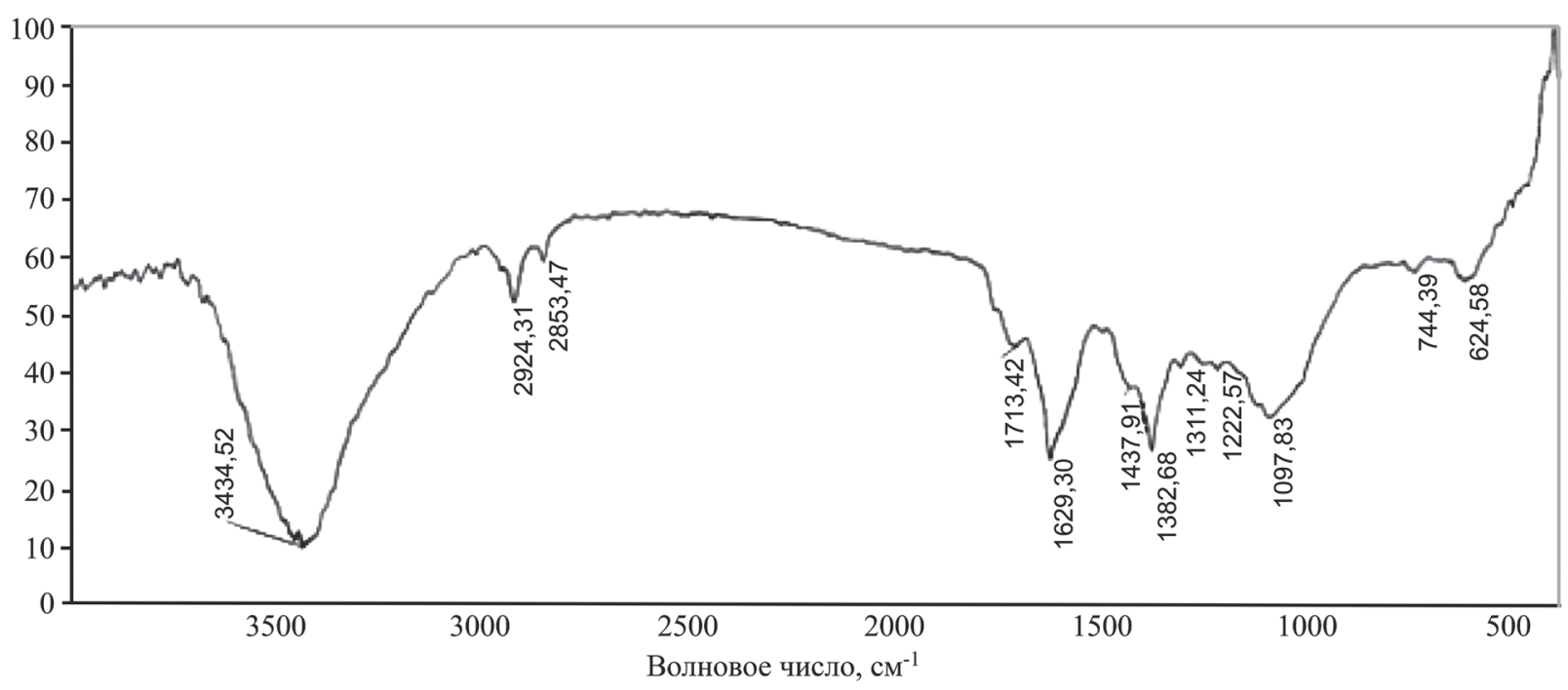

Рис. 4. ИК- спектр МОКС на основе $\mathrm{CuPc}(\mathrm{COOH})_{8}$ IR (KBr): v, $\mathrm{cm}^{-1} 2924\left(-\mathrm{CH}_{3} v_{a s}\right), 2853\left(-\mathrm{CH}_{2}-v_{a s}\right), 1629(-\mathrm{C}=\mathrm{O} \mathrm{st}), 1382(-\mathrm{C}-\mathrm{N} \mathrm{st})$ 


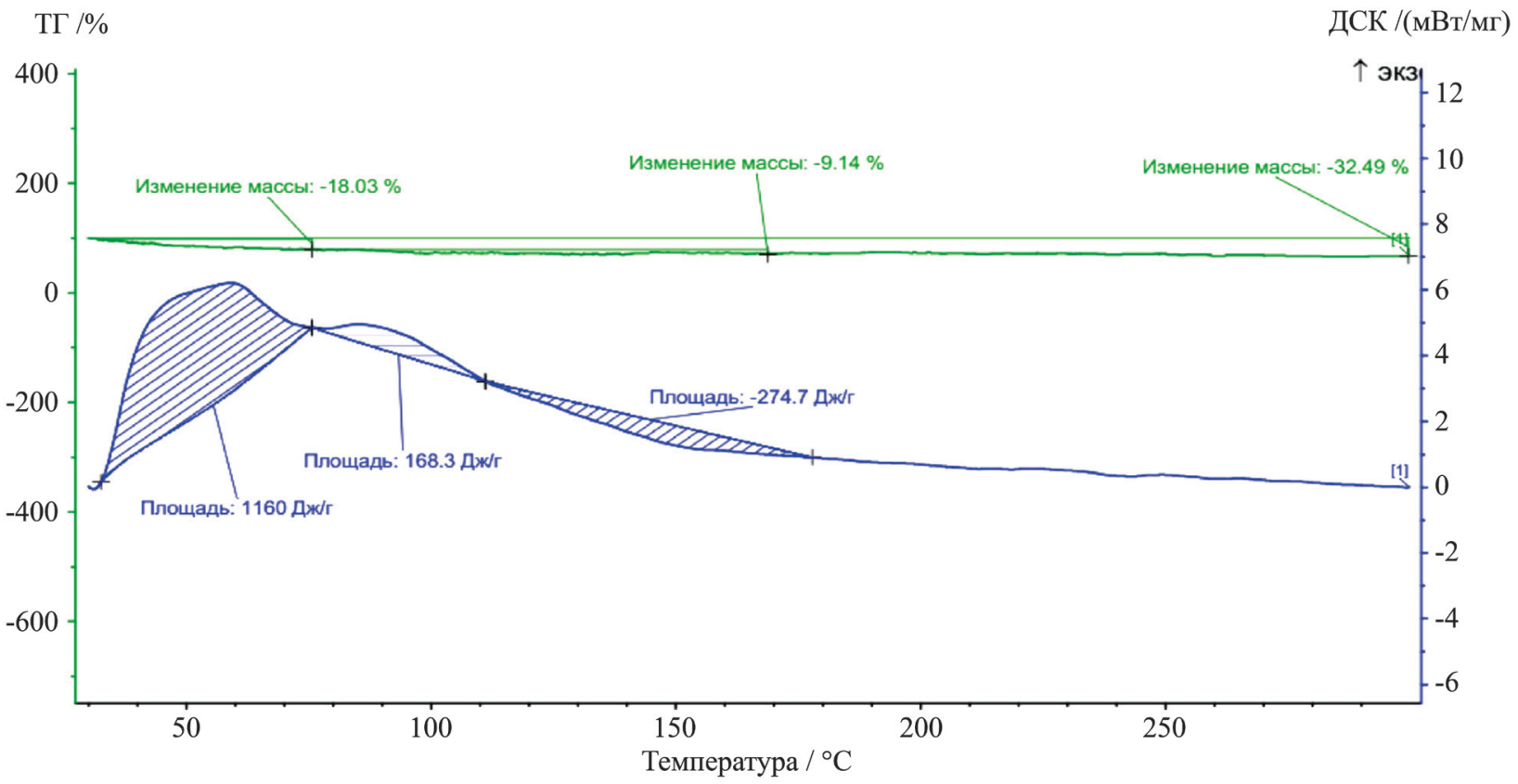

Рис. 5. Кривая ДСК и ТГ для МОКС на основе СuРc(COOH) (в атмосфере Ar/-/Ar nри температуре om 30 до $300^{\circ} \mathrm{C}$ )
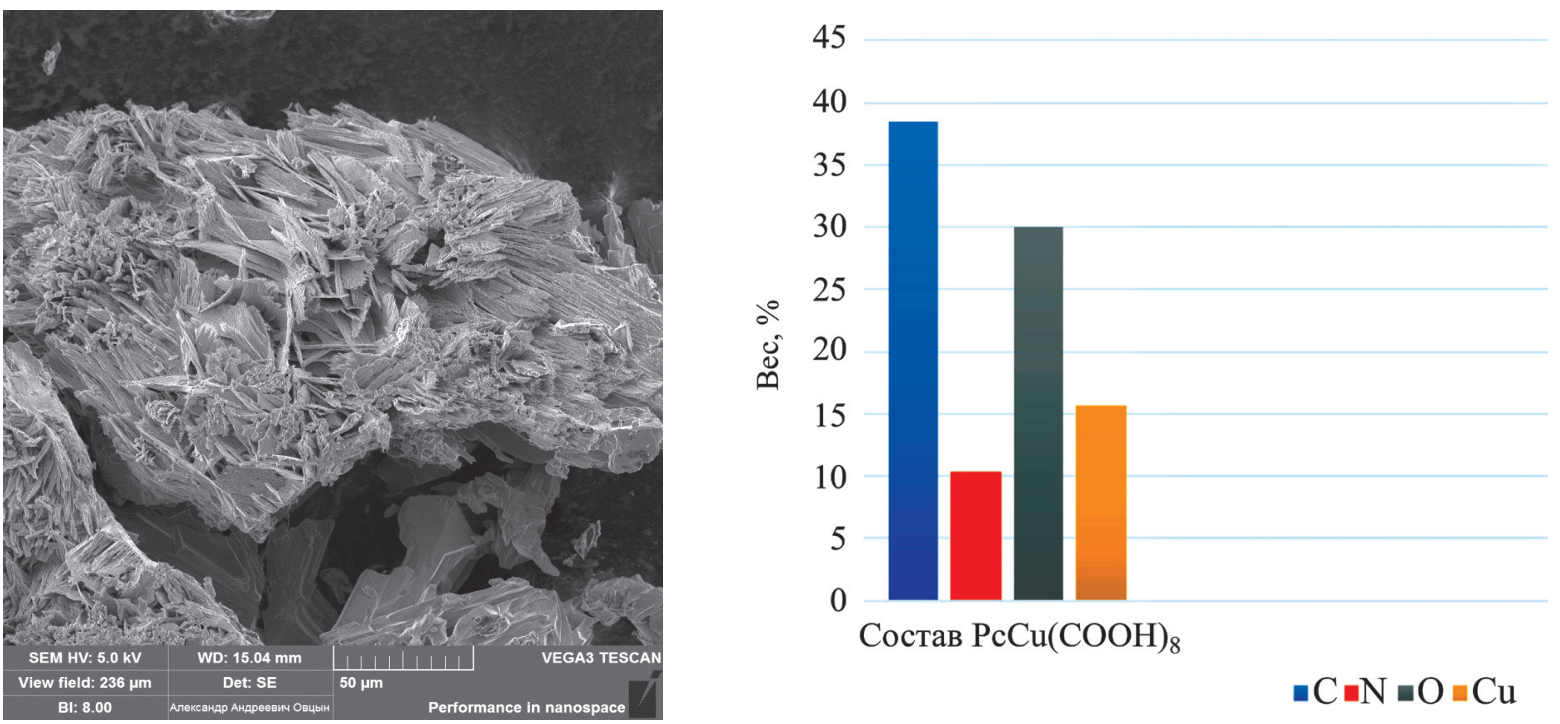

Рис. 6. Микрофотография образца МОКС на основе СuРc(COOH) 8 (50 мкм) и его элементный состав по данным СЭМ

Термическая устойчивость синтезированного МОКС на основе октакарбоксифталоцианината алюминия (Ш) была исследована методом ДСК Согласно данным термического анализа установлено, что полученное соединение в интервале температур от $30^{\circ} \mathrm{C}$ до $400^{\circ} \mathrm{C}$ в инертных условиях теряет менее $31 \%$ от своей массы (Рис. 8).

Синтез МОКС на основе октакарбоксифталоцианината цинка (II). В реакционный сосуд, снабженный магнитной мешалкой, загружа- ли октакарбоксифталоцианинат цинка (II). (1d) 40 мг (0,04 ммоль), терефталевую кислоту 20 мг (0,12 ммоль) и 3 мл ДМФА. Колбу, закрытую заглушкой, помещали в микроволновой реактор «CEM Discover labmate microwave reactor» и peакционную смесь выдерживали в течение 50 минут при давлении 70 Па, при температуре $150{ }^{\circ} \mathrm{C}$ и мощности 100 Вт. Охлажденный продукт реакции промывали дистиллированной водой, этанолом до исчезновения окраски промывной жидко- 


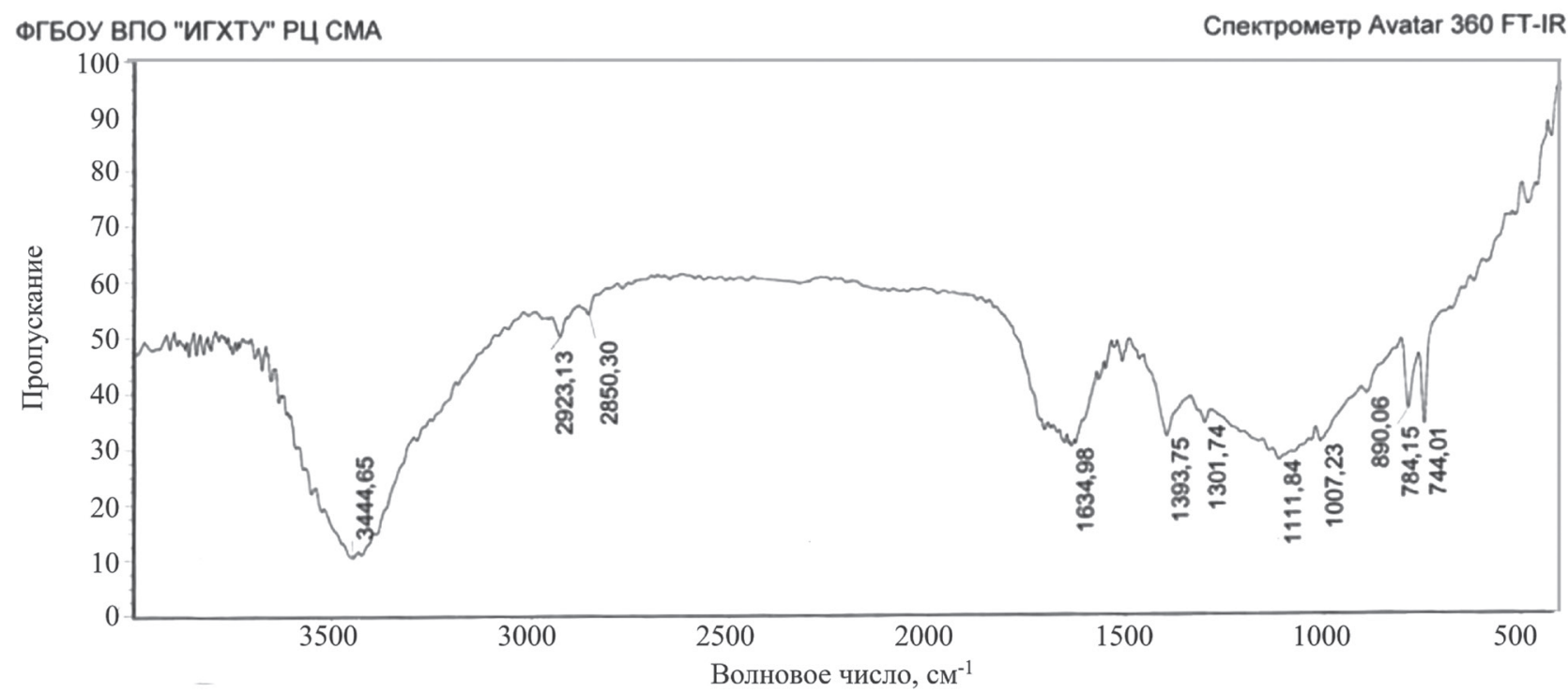

Рис. 7. ИК-спектр МОКС на основе $\mathrm{Al}(\mathrm{OH}) \mathrm{Pc}(\mathrm{COOH})_{8}$ $\operatorname{IR}(\mathrm{KBr}): \mathrm{v}, \mathrm{cm}^{-1} 2923\left(-\mathrm{CH}_{3} \mathrm{v}_{a s}\right), 2850\left(-\mathrm{CH}_{2}-\mathrm{v}_{a s}\right), 1634(-\mathrm{C}=\mathrm{O} s t), 1393(-\mathrm{C}-\mathrm{N} s t)$

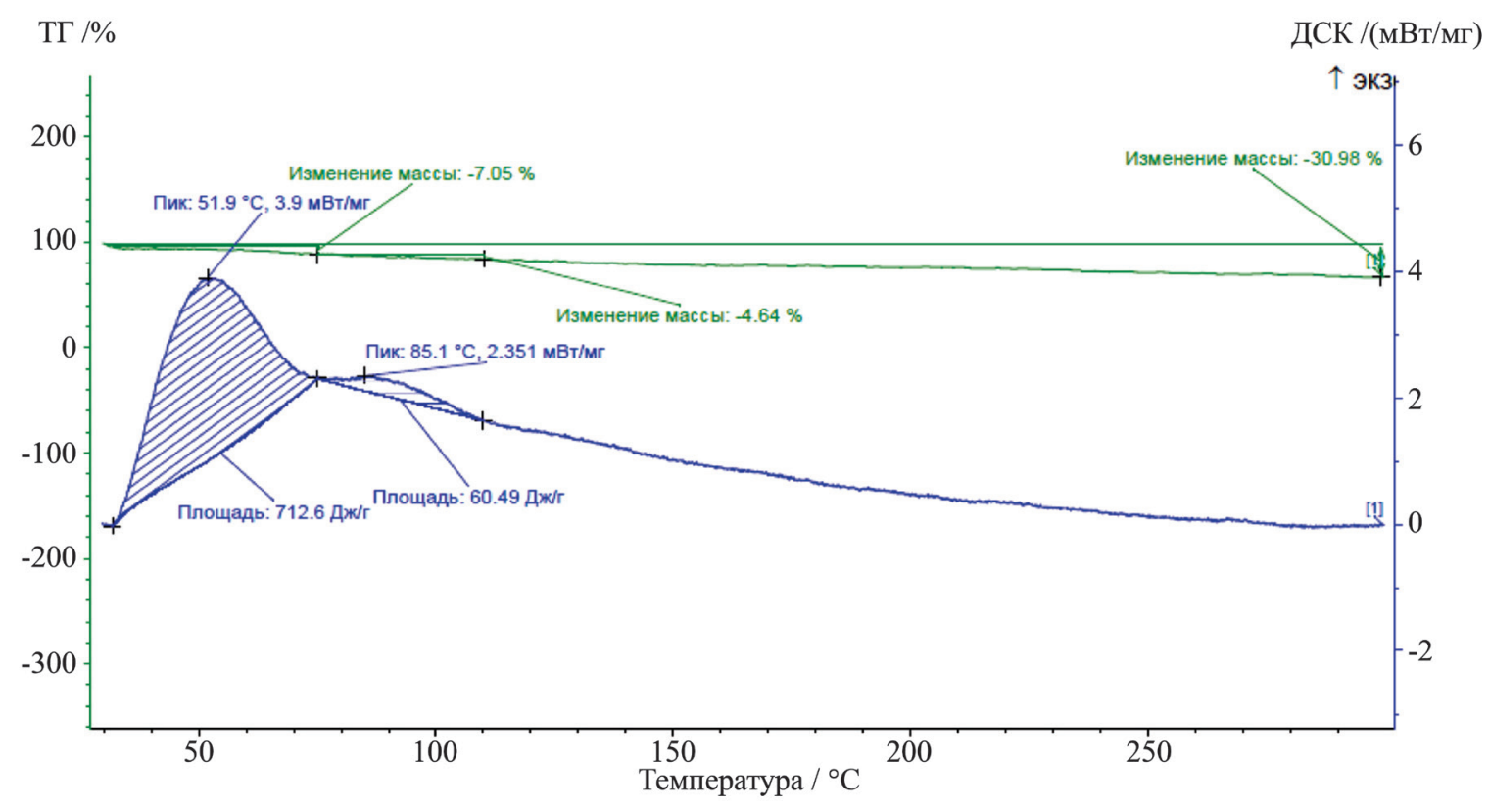

Рис. 8. Кривая ДСК и ТГ для МОКС на основе $\mathrm{Al}(\mathrm{OH}) \mathrm{Pc}(\mathrm{COOH})_{8}$ при окислительных условиях (сжигание материала в атмосфере $\mathrm{Ar} / \mathrm{O}_{2} / \mathrm{Ar}$ при температуре от 30 до $400{ }^{\circ} \mathrm{C}$ )

сти. Полученный плав представляет собой кристаллический порошок темно зеленого цвета. Выход продукта составил $55 \%$.

ИК-спектр полученного продукта свидетельствуют о наличии октакарбоксифталоцианината цинка (II) в синтезированном соединении (Рис. 9).

Термическая устойчивость синтезированного МОКС на основе $\mathrm{ZnPc}(\mathrm{COOH})_{8}$ была исследована методом ДСК на приборе NETZSCH STA 449F3. Согласно данным термического анализа установ- лено, что полученное соединение в интервале температур от $30^{\circ} \mathrm{C}$ до $300^{\circ} \mathrm{C}$ в инертных условиях теряет менее $22 \%$ от своей массы.

Разработанная методика получения металлорганических координационных соединений на основе описанных металлокомплексов в условиях МВИ успешно была применена к другим октакарбоксифталоцианинатам металлов и может быть использована для формирования МОКС на основе других фталоцианинов. 


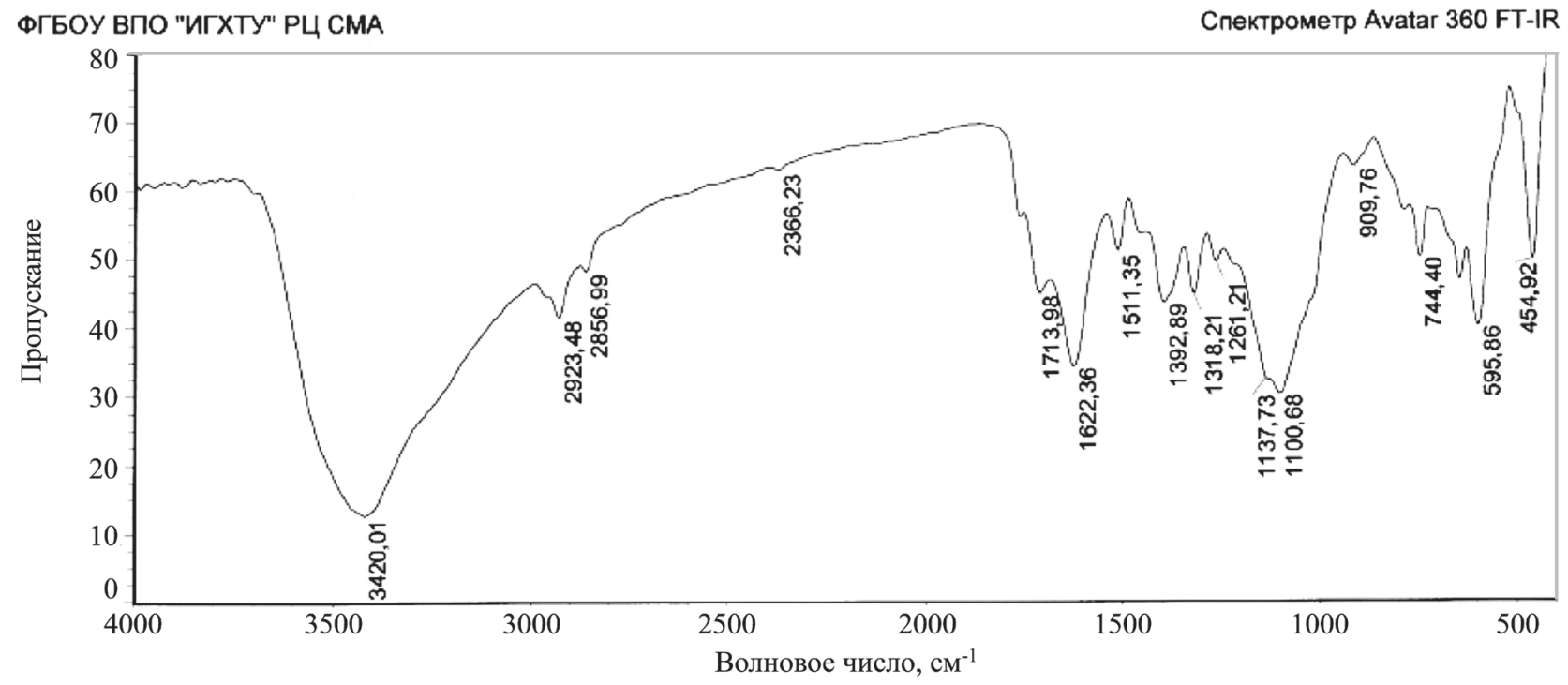

Рис. 9. ИК- спектр МОКС на основе $\mathrm{ZnPc}(\mathrm{COOH})_{8}$ IR (KBr): v, $\mathrm{cm}^{-1} 2923\left(-\mathrm{CH}_{3} v_{a s}\right), 2856\left(-\mathrm{CH}_{2}-v_{a s}\right), 1622(-\mathrm{C}=\mathrm{O} s t), 1511\left(-\mathrm{CH}_{2}-\delta\right), 1392(-\mathrm{C}-\mathrm{Nst})$

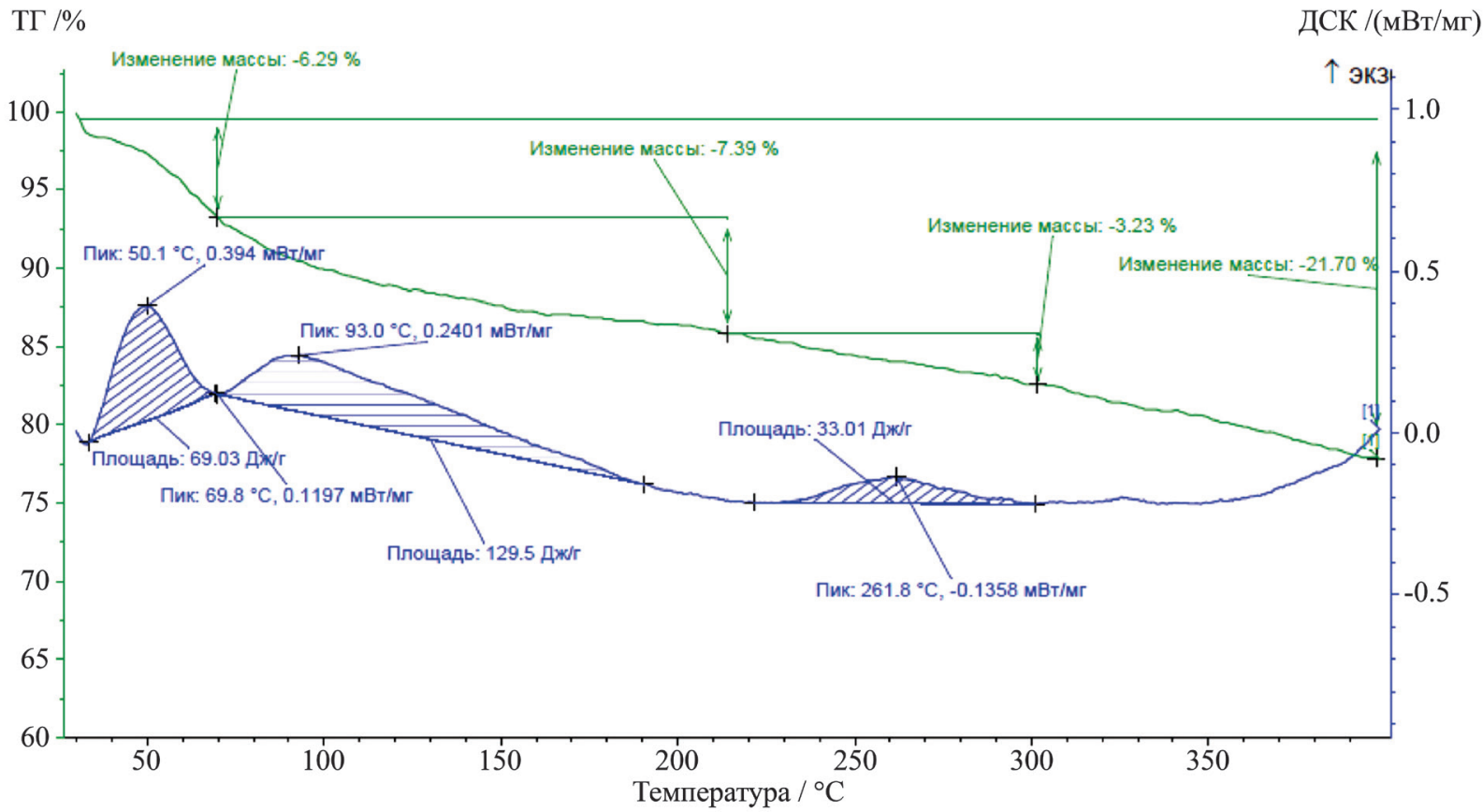

Рис. 10. Кривая ДСК и ТГ для МОКС на основе $\mathrm{ZnPc}(\mathrm{COOH})_{8}$ при окислительных условиях (сжигание материала в атмосфере $\mathrm{Ar} / \mathrm{O}_{2} / \mathrm{Ar}$ при температуре от 30 до $400{ }^{\circ} \mathrm{C}$ )

Синтез МОКС на основе тетракарбоксифталоцианината меди (II). В реакционный сосуд, снабженный магнитной мешалкой, загружали тетракарбоксифталоцианинат меди (1a) 40 мг (0,04 ммоль), терефталевую кислоту 20 мг (0,12 ммоль) и 3 мл ДМФА. Пробирку, закрытую заглушкой, помещали в микроволновой реактор «CEM Discover labmate microwave reactor» и реакционную смесь выдерживали в течение 50 минут при давлении 70 Па, при температуре $150{ }^{\circ} \mathrm{C}$ и мощности 100 Вт. Охлажденный продукт реакции промывали дистиллированной водой, этанолом до исчезновения окраски промывной жидкости. Полученный плав представляет собой кристаллический порошок зеленоватосинего цвета. Выход продукта составил $90 \%$.

Полученное соединение было исследовано методом ИК-спектроскопии на спектрофотометре Avatar 360 FT-IR ESP. ИК-спектры позволяют су- 


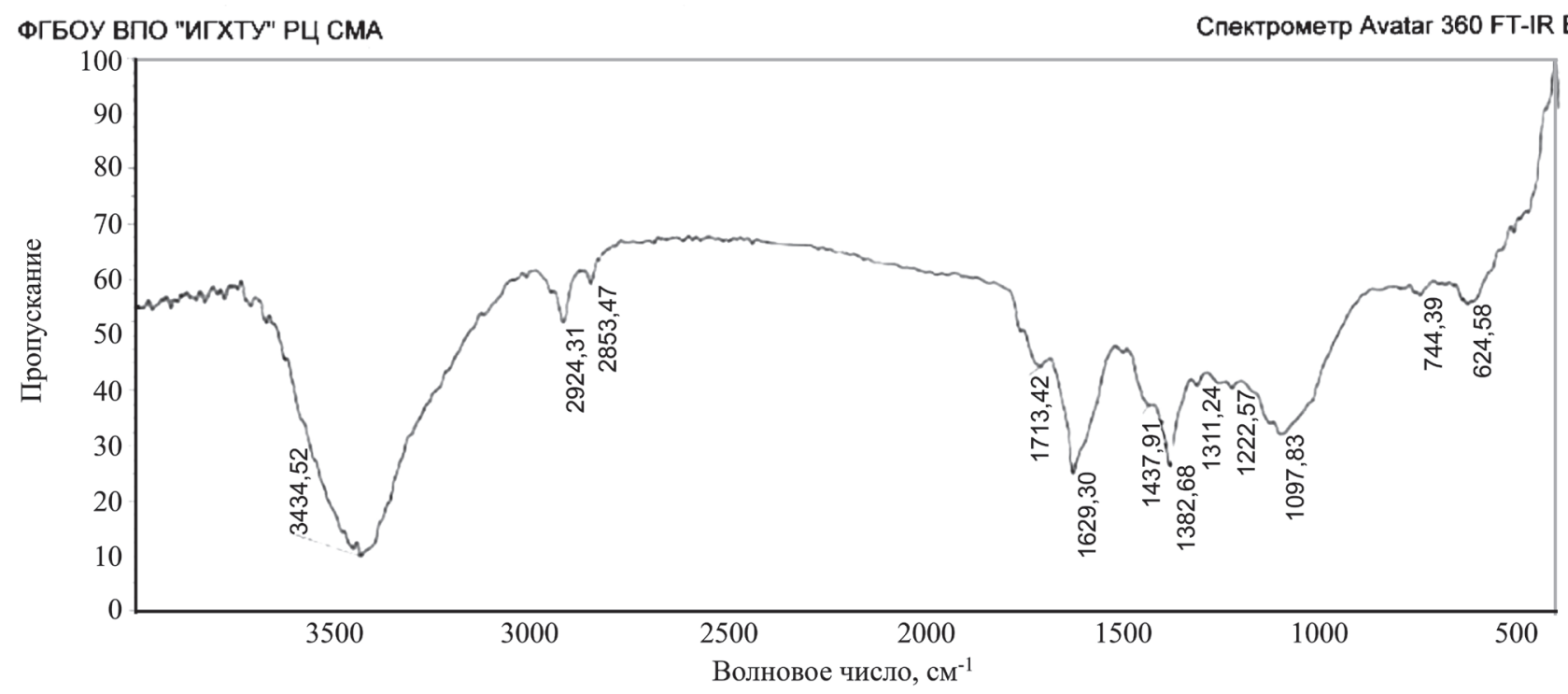

Рис. 11. ИК-спектр МОКС на основе $\mathrm{CuPc}(4,5-\mathrm{COOH})_{4}$ IR (KBr): v, $\mathrm{cm}^{-1} 2924\left(-\mathrm{CH}_{3} v_{a s}\right), 2853\left(-\mathrm{CH}_{2}-v_{a s}\right), 1629(-\mathrm{C}=\mathrm{O} \mathrm{st}), 1382(-\mathrm{C}-\mathrm{N} \mathrm{st})$

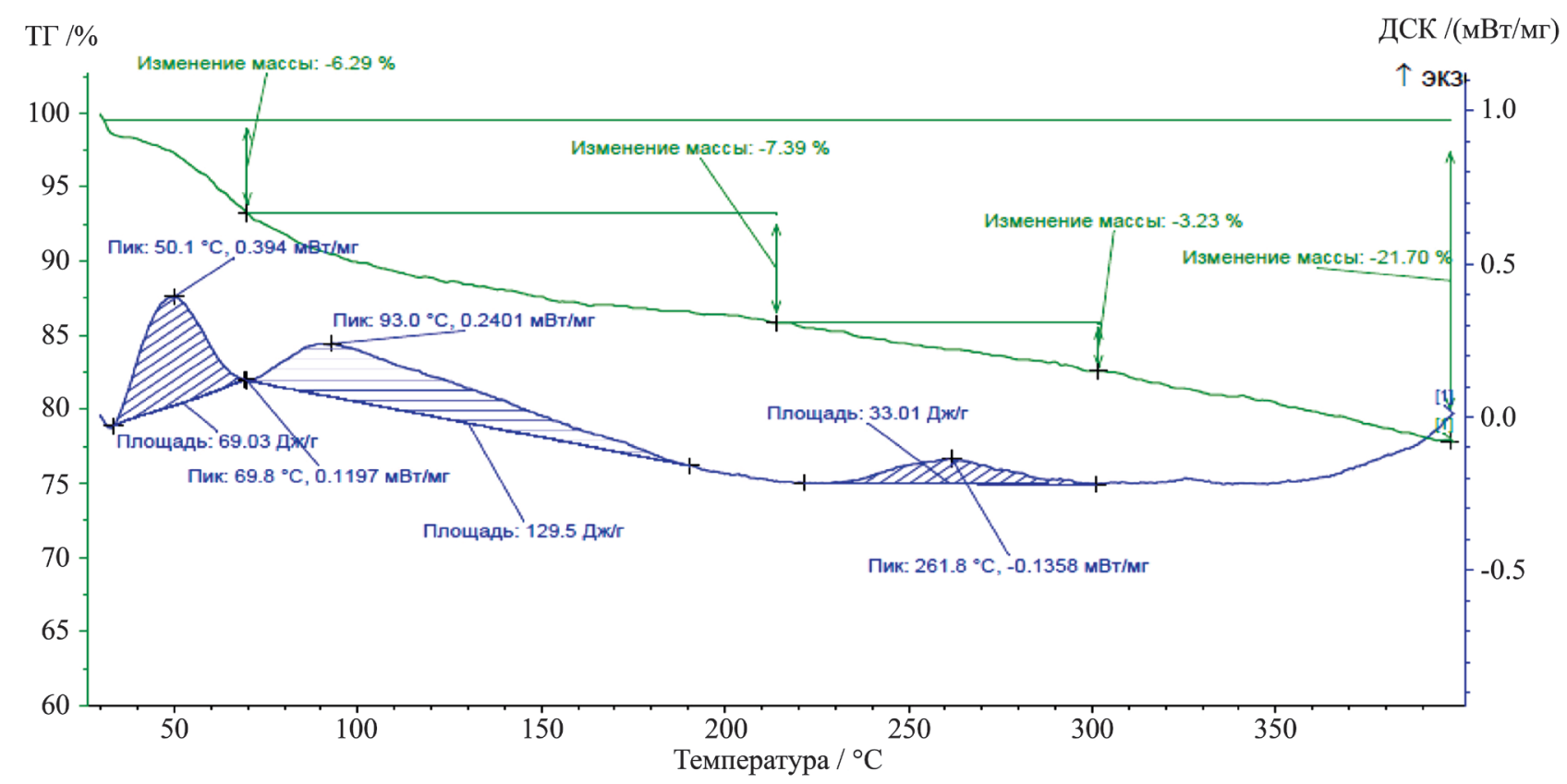

Рис. 12. Кривая ДСК и ТГ для $\mathrm{CuPc}(4,5-\mathrm{COOH})_{8}$ при окислительных условиях (сжигание материала в атмосфере Ar/O_/Ar при температуре от 30 до $400{ }^{\circ} \mathrm{C}$ )

дить о наличии тетракарбоксифталоцианината меди(II) в синтезированном МОКС (Рис. 11). Сравнительный анализ полученных данных позволил идентифицировать синтезированное соединение как идентичное МОКС, полученному сольватотермическим способом [21].

Исследования термической устойчивости синтезированного МОКС показали, что МОКС в интервале температур от $30^{\circ} \mathrm{C}$ до $400{ }^{\circ} \mathrm{C}$ в инертных условиях теряет менее $22 \%$ от своей массы (Рис. 12).
Микрофотография МОКС на основе $\mathrm{CuPc}(\mathrm{COOH})_{4}$ и данные его элементного анализа, полученного с помощью СЭМ, приведены на рис. 13.

Методами ИК-спектроскопии, дифференциальной сканирующей калориметрии, электронной сканирующей микроскопии были исследованы все образцы МОКС, после испытания их в качестве катализаторов различных окислительных процессов, таких как окисление аскорбиновой кислоты, 

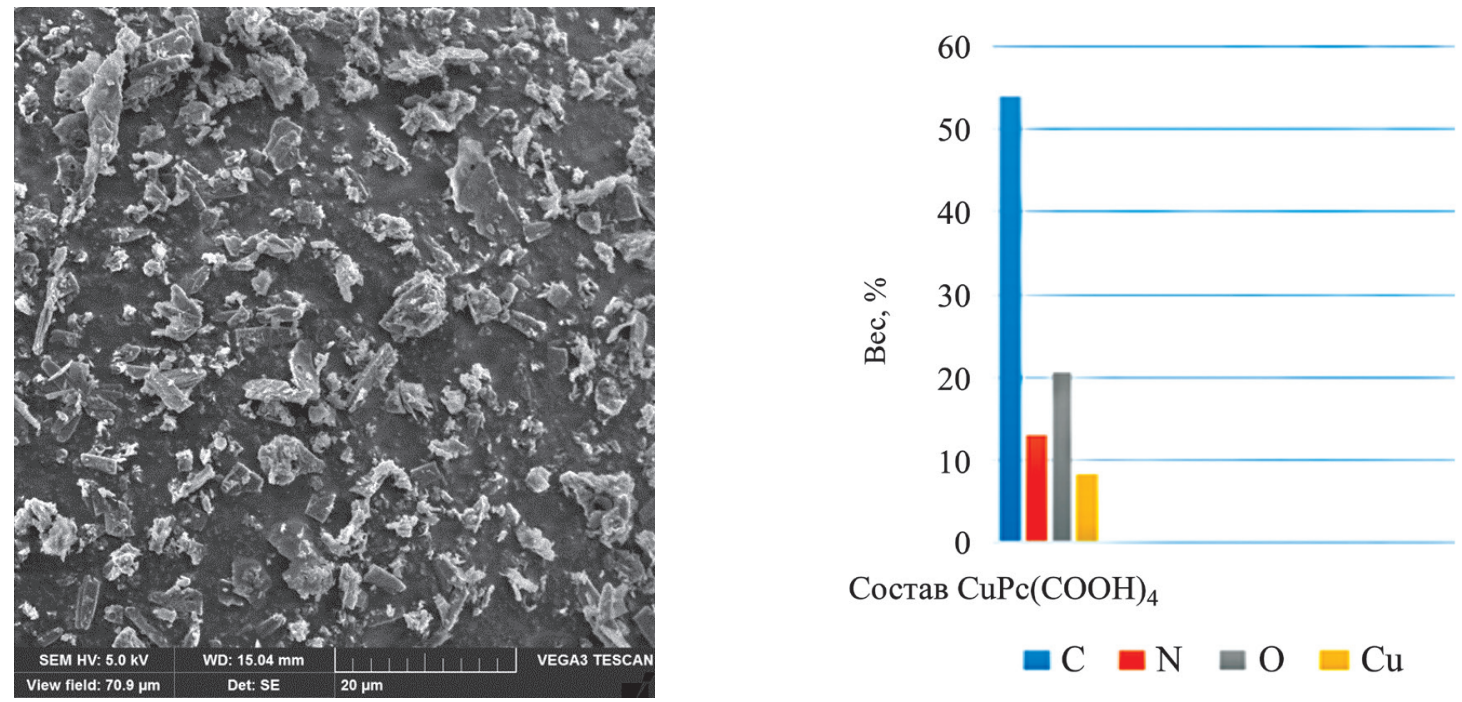

Состав $\mathrm{CuPc}(\mathrm{COOH})_{4}$

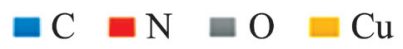

Рис. 13. Микрофотография МОКС на основе СuРc(COOH) $(50$ мкм) и его элементный состав по данным СЭМ

моносахаридов, морина и др. Полученные характеристики свидетельствуют о том, что все полученные МОКС на основе фталоцианинатов металлов в окислительных процессах остаются неизменными и являются перспективными функциональными материалами для редокс превращений различных биологически активных соединений.

Таким образом, в условиях микроволнового излучения получены металлоорганические каркасные структуры методом конденсации и терефталевой кислоты с металлокомплексами октакарбоксифталоцианината или тетракарбоксифталоцианина в диметилформамиде. Исследования физико-химических свойств полученных МОКС показывают их высокую стабильность и неизменность свойств, которые сохраняется в процессе испытаний их в условиях различных окислительновосстановительных процессов, что позволяет рассматривать их как новые перспективные функциональные материалы для модификации биологически активных соединений.

Работа выполнена с использованием ресурсов Центра коллективного пользования научным оборудованием ФГБОУ ВО «ИГХТУ», в рамках Государственного задания (проект №FZZW-2020-0008) и при финансовой поддержке Российского фонда фундаментальных исследований (грант № 18-3300456 мол_а).

\section{Лumepamypa}

1. Койфман О.И., Агеева Т.А. Порфиринполимеры: Синтез, свойства, применение. / М.: ЛЕНАНД, 2018. 300 c.
2. Койфман О.И., Агеева Т.А. Металлопорфирины в макромолекулярной химии. Изв. Академии наук. Сер. химическая. 2015 (9). Р. 2001-2011.

3. Ломова Т.Н. Аксиально координированные металлопорфирины в науке и практике. М.: КРАСАНД. 2018. 700 c.

4. Sanders J.K.M., Bampos N., Clude-Watson Z., Darling S.L., Hawley J.C., Kim H.-J. Mak C.C., Webb S.I. Axial Coordination Chemistry of Metalloporphyrins. / In: The Porphyrin Handbook. / K.M. Kadish, K.M. Smith, R. Guilard (Eds.). Academ. Press: N. Y. 2000. V. 3. P. 1-48.

5. Березин Б.Д., Березин М.Б. Экстракоординация молекул на металлопорфиринах как один из факторов каталитической и ферментативной активности порфиринов. / В кн.: Биологически активные вещества в растворах: структура, термодинамика, реакционная способность. / Под ред. А. М. Кутепова. М.: Наука. 2001. С. 254-297.

6. Мамардашвили Г.М., Мамардашвили Н.Ж., Койфман О.И. Самоорганизующиеся системы на основе порфиринов. Успехи химии. 2008. Т. 77(1). С. 61-77.

7. Sayed A.M., Razavi A.A. Introduction to Functional Metal-Organic Frameworks/ Dec 2020 DOI: 10.1002/9781119640998.ch1 In book: Functional Metal Organic Frameworks (pp. 1-14)

8. Parnham E.R., Morris R.E. Ionothermal Synthesis of Zeolites, Metal-Organic Frameworks, and Inorganic-Organic Hybrids. Acc. of Chem. Res. 2007. V. 40. P. 1005-1013.

9. Czaja A.U., Trukhan N., Müller U. Industrial Applications of Metal-Organic Frameworks. Chem. Soc. Rev. 2009. V. 38. P. 1284-1293.

10. Gao W.-Y., Chrzanowskia M., Ma S. Metal-metalloporphyrin frameworks: a resurging class of functional materials. Chem. Soc. Rev. 2014. V. 43. P. 5841-5866.

11. Wang Y., Hou Q., Ju M., Li W. New Developments in Material Preparation Using a Combination of Ionic Liquids and Microwave Irradiation. Nanomaterials. 2019. V. 9. P. 647. 
12. Kosal M.E., Chou O.-H, Wilson S.R., Suslick K.S. A functional zeolite analogue assembled from metalloporphyrins. Natre materials. 2002. V. 1. P. 118.

13. Al-Kutubi H., Gascon J., Sudhçlter E. J. R., Gascon L.R. Electrosynthesis of Metal-Organic Frameworks: Challengesand Opportunities. J. Chem. Electro. Chem. 2015. V. 2. P. $462-474$.

14. Kockrick E., Lescouet T., Kudrik E.V., Sorokin A.B., Farrusseng D. Synergistic effects of encapsulated phthalocyanine complexes in MIL-101 for the selective aerobic oxidation of tetralin. Chem. Commun. 2011. V. 47(5). P. 1562-1564.

15. Zalomaeva O.V., Kovalenko K.A., Chesalov Y.A., Mel'gunov M.S., Zaikovskii V.I., Kaichev, V.V., Sorokin A.B., Kholdeeva O.A., Fedin V.P. Iron tetrasulfophthalocyanine immobilized on metal organic framework MIL-101: synthesis, characterization and catalytic properties. Dalton Trans. 2011. V. 40(7). P. 1441-1444.

16. Boroujen M.B., Hashemzadeh A., Shaabani A., Amini M.M. In situ synthesis of metallophthalo-cyanines into pores of MIL-101: A novel and green strategy for preparation of host-guest catalysts. Appl. Organomet. Chem. 2017. V. 31(10). P. e3715.

17. He W.-L., $W u$ C.-D. Incorporation of Fe-phthalocyanines into a porous organic framework for highly efficient photocatalytic oxidation of arylalkanes. App. Catalysis B: Environmental. 2018. V. 234. P. 290-295.

18. Metal-Organic Framework Materials. Lukehart C. M., MacGillivray L. R. Wiley, 1 edn 2014. 589 p.

19. Агеева Т.А., Головашова Е.С., Кудрик Е.В., Майзлиш B.E., Менгель Я.C. Способ получения металлоорганических каркасных соединений с октакарбоксифталоцианинатами металлов в качестве основной структурной единицы. // Патент РФ №2611438. БИ №6 от 22.02.2017. 2017.

20. Головашова Е.С., Менгель Я.С., Агеева Т.А., Кудрик E.B., Койфман О.И. Синтез и свойства нового наноматериала на основе октакарбоксифталоцианината меди. Ж. физ. химии. 2017. Т. 91. Р. 2122-2125.

21. Golovashova E.S., Kulev V.A., Kudrik E.V., Moiseeva K.E., Ageeva T.A., Koifman O.I. A New Way of Synthesizing Photoactive Metal-Organic Framework Compounds with Macrocyclic Tetrapyrrole Ligands and Their Activity in the Photo-Oxidation of Anthracene under Visible Light. Russ. J. Phys. Chem., A. 2020. V. 94(3). P. 638-640.

22. Функциональные материалы на основе тетрапиррольных макрогетероциклических соединений / под ред. О.И. Койфмана. М.: Ленанд, 2019 - 838 с.

23. Койфман О.И., Агеева Т.А., Белецкая И.П. и др. Макрогетероциклические соединения - ключевое звено в создании новых функциональных материалов и молекулярных устройств. Макрогетероциклы. 2020. T. 13(4). С. 311-467.

\section{References}

1. Koifman O.I., Ageeva T.A. Porphyrin Polymers: Synthesis, Properties, Applications. Moscow: LENAND. 2018. 300 p.
2. Koifman O.I., Ageeva T.A. Metalloporphyrins in Macromolecular Chemistry. Russian Chemical Bulletin. 2015. V. 64(9). P. 2001-2011.

3. Lomova T.N. Axially Coordinated Metalloporphyrins in Science and Practice. Moscow: KRASAND. 2018. 700 p.

4. Sanders J. K. M., Bampos N., Clude-Watson Z., Darling S.L., Hawley J.C., Kim H.-J. Mak C. C., Webb S. I. Axial Coordination Chemistry of Metalloporphyrins. / In: The Porphyrin Handbook. / K. M. Kadish, K. M. Smith, R. Guilard (Eds.). Academ. Press: N. Y. 2000. V. 3. P. 1-48.

5. Berezin B.D., Berezin M.B. Extracoordination of molecules on metalloporphyrins as one of the factors of the catalytic and enzymatic activity of porphyrins. / In book "Biologically active substances in solutions: structure, thermodynamics, reactivity". / Ed. A.M. Kutepov, Moscow: Nauka, 2001. P. 245-297.

6. Mamardashvili G.M., Mamardashvili N.Zh., Koifman O.I. Self-assembling systems based on porphyrins. Russ. Chemical Reviews. 2008 . V. 77 (1). P. 59-75.

7. Sayed A. M., Razavi A. A. Introduction to Functional Metal-Organic Frameworks/ Dec 2020 DOI: 10.1002/9781119640998.ch1 In book: Functional Metal Organic Frameworks (pp.1-14)

8. Parnham E.R., Morris R.E. Ionothermal Synthesis of Zeolites, Metal-Organic Frameworks, and InorganicOrganic Hybrids // Acc. of Chem. Res. 2007. V. 40. P. 1005-1013.

9. Czaja A.U., Trukhan N., Müller U. Industrial Applications of Metal-Organic Frameworks. Chem. Soc. Rev. 2009. V. 38. P. 1284-1293.

10. Gao W.-Y., Chrzanowskia M., Ma S. Metal-metalloporphyrin frameworks: a resurging class of functional materials. Chem. Soc. Rev. 2014. V. 43. P. 5841-5866.

11. Wang Y., Hou Q., Ju M., Li W. New Developments in Material Preparation Using a Combination of Ionic Liquids and Microwave Irradiation. Nanomaterials 2019. V. 9. P. 647.

12. Kosal M. E., Chou O.-H, Wilson S. R., Suslick K.S. A functional zeolite analogue assembled from metalloporphyrins. Nature materials. 2002. V. 1. P. 118.

13. Al-Kutubi H., Gascon J., Sudhçlter E.J.R., Gascon L.R. Electrosynthesis of Metal-Organic Frameworks: Challengesand Opportunities. J.ChemElectroChem 2015. V. 2. P. $462-474$.

14. Kockrick E., Lescouet T., Kudrik E. V., Sorokin A. B., Farrusseng D. Synergistic effects of encapsulated phthalocyanine complexes in MIL-101 for the selective aerobic oxidation of tetralin. Chem. Commun. 2011. V. 47(5). P. 1562-1564.

15. Zalomaeva O. V., Kovalenko K. A., Chesalov Y. A., Mel'gunov M. S., Zaikovskii V. I., Kaichev, V. V., Sorokin A. B., Kholdeeva O. A., Fedin V. P. Iron tetrasulfophthalocyanine immobilized on metal organic framework MIL-101: synthesis, characterization and catalytic properties. Dalton Trans. 2011. V. 40(7). P. 1441-1444.

16. Boroujen M. B., Hashemzadeh A., Shaabani A., Amini $M$. M. In situ synthesis of metallophthalocyanines into pores of MIL-101: A novel and green strategy for prepa- 
ration of host-guest catalysts. Appl. Organomet. Chem. 2017. V. 31(10). P. e3715.

17. He W.-L., Wu C.-D. Incorporation of Fe-phthalocyanines into a porous organic framework for highly efficient photocatalytic oxidation of arylalkanes. App. Catalysis B: Environmental. 2018. V. 234. P. 290-295.

18. Metal-Organic Framework Materials. Lukehart C. M., MacGillivray L. R. Wiley, 1 edn 2014. 589 p.

19. Ageeva T.A., Golovashova E.S., Kudrik E.V., Maizlish V.E., Mengel'Y.S. A method for producing metallorganic frame compounds with metallocomplex of octacarboxypthalocyanine as the main structural unit. Patent RF № 2611438, BI 2017. No 6. 22.02.2017.

20. Golovashova E.S., Mengel' Y.S., Ageeva T.A., Kudrik E.V., Koifman O.I. Synthesis and Properties of a New Nanomaterial Based on Copper octacarboxyphthalo- cyaninate. Russ. J. of Phys. Chemistry A. 2017. V. 91 (12). P. 2437-2440.

21. Golovashova E.S., Kulev V.A., Kudrik E.V., Moiseeva K.E., Ageeva T.A., Koifman O.I. A New Way of Synthesizing Photoactive Metal-Organic Framework Compounds with Macrocyclic Tetrapyrrole Ligands and Their Activity in the Photo-Oxidation of Anthracene under Visible Light. Russ. J. Phys. Chem., A. 2020. 94(3). P. 638-640.

22. Functional Materials Based on Tetrapyrrolic Compounds. / Ed. O.I. Koifman - Moscow: LENAND, 2019, 838 c.

23. Koifman O.I., Ageeva T.A., Beletskaya I.P. et al. Macroheterocyclic Compounds - a Key Building Block in New Functional Materials and Molecular Devices. Macroheterocycles 2020. V. 13(4). P. 311-467. 